\title{
Migration and brackish environment use of Prochilodus lineatus (Characiformes: Prochilodontidae) inferred by Sr:Ca ratio transects of otolith
}

\author{
Esteban Avigliano ${ }^{1}$, Jorge Pisonero ${ }^{2}$, Alejandro Dománico ${ }^{3,4}$, Sebastián Sánchez ${ }^{5}$ and \\ Alejandra V. Volpedo ${ }^{1}$
}

The streaked prochilod, Prochilodus lineatus, represents the most important fishery in the La Plata Basin (South America). Our objective was to analyze brackish environment use by the streaked prochilod captured from Paraná and Uruguay rivers. To accomplish this, lapillus otolith sections were analyzed for $\mathrm{Sr}$ :Ca with laser ablation-inductively coupled plasma-mass spectrometry (LA ICP-MS) to infer habitat use of fish. To the interpretation of transects, a threshold that represents the transition between freshwater and brackish environments was calculated using the Sr:Ca ratio of the otolith edge of specimens captured in the first section of the La Plata Estuary (salinity $\geq 0.5$ PSU). The percentage of fish using the estuary was higher in the Paraná (37\%) than the Uruguay River (5\%). Change-point analysis showed that fish entered the estuary between 1 and 3 times throughout life at a wide range of ages (0-15 years). These incursions had no obvious periodicity. This information should be integrated into future management actions, which should also be specific to each area since migration patterns differ between the major rivers of the basin.

Keywords: Connectivity, Freshwater resident, Laser ablation, River migration, Streaked prochilod.

El sábalo, Prochilodus lineatus, representa la pesquería más importante en la Cuenca del Río de la Plata (Sudamérica). Nuestro objetivo fue analizar el uso del hábitat estuarino del sábalo proveniente de los ríos Uruguay y Paraná. Para esto, se analizó la relación Sr:Ca en secciones de otolitos lapilli por ablación láser acoplada a espectrometría de masas con fuente de plasma de acoplamiento inductivo (LA ICP-MS) para inferir el uso de hábitat. Para interpretar las transectas, un umbral que representa la transición entre los ambientes de agua dulce y estuarino, fue calculado usando la relación Sr:Ca del borde del otolito de especímenes capturados en la primera sección del estuario del Plata (salinidad $\geq 0.5$ UPS). El porcentaje de peces que usaron el estuario fue más elevado para el Paraná (37\%) en relación al Uruguay (5\%). El análisis de cambio puntual mostro que los individuos ingresan al estuario entre 1 a 3 veces a lo largo de la vida en un amplio rango de edades (0-15 años). Las incursiones no mostraron una periodicidad notoria. Esta información debería integrarse a futuras acciones de manejo que deberían ser específicas para cada área considerando los patrones de migración que difieren entre los grandes ríos de la Cuenca.

Palabras clave: Ablación laser, Agua dulce residente, Conectividad, Migración de rio, Sábalo.

\section{Introduction}

The La Plata Basin, with $3,170,000 \mathrm{~km}^{2}$ is the fluvialmarine system with larger surface of the Americas, after the Amazon. This basin goes through 5 countries in South America and is located between latitudes $17^{\circ} \mathrm{S}$ and $36^{\circ}$
S, with a north-south current direction (Fig. 1). Its most important rivers are the Paraná (4,000 km long), Paraguay (2,600 km long), Uruguay (1,800 km long) and Pilcomayo (1,500 km long) (Fig. 1) (Guerrero et al., 1997). These rivers drain into the Paraná Delta, which terminates in the La Plata Estuary (Guerrero et al., 1997). The main fishery resource

\footnotetext{
${ }^{1}$ Instituto de Investigaciones en Producción Animal (INPA-CONICET-UBA), Facultad de Ciencias Veterinarias, Universidad de Buenos Aires (UBA), Av. Chorroarín 280, C1427CWO Buenos Aires, Argentina. (EA) estebanavigliano@conicet.gov.ar (corresponding author), (AV) avolpedo@fvet.uba.ar

${ }^{2}$ Departamento de Física, Facultad de Ciencias, Universidad de Oviedo, Calvo Sotelo s/n, 33007 Oviedo, Spain. pisonerojorge@uniovi.es ${ }^{3}$ Laboratorio de la Dirección de Pesca Continental, Subsecretaría de Pesca y Acuicultura, Ministerio de Agroindustria. Alférez Pareja 125, C1107BJD Buenos Aires, Argentina. aadomanico@gmail.com

${ }^{4}$ Comisión de Investigaciones Científicas (CIC), Calle 526 s/n, 1900 La Plata, Buenos Aires, Argentina.

${ }_{5}^{5}$ Instituto de Ictiología del Nordeste, Facultad de Ciencias Veterinarias, Universidad Nacional del Nordeste, CONICET, Sargento Cabral 2139, 3400 Corrientes, Argentina. sebasanchez58@hotmail.com
} 
of the basin is the streaked prochilod, Prochilodus lineatus (Valenciennes, 1837), whose catch volumes have exceeded $36,000 \mathrm{t} / \mathrm{year}$, from the middle portion of the Paraná River (Sverlij et al., 1993; MINAGRO, 2016). Streaked prochilod reproductive cycle is correlated with the natural flood pulse regime (Neiff, 1999) with migrations upstream and spawning in open river waters coupled to the flooding periods as a mechanism of dispersion of eggs (Sverlij et al., 1993). According to Bonetto et al. (1981), Delfino, Baigun (1985) and Espinach Ros et al. (1998), the streaked prochilods migrate over $1,000 \mathrm{~km}$ to feed and reproduce.

Considering that the La Plata estuary (Uruguay and Argentina) is one of the target sites for commercial fishing, life history information on streaked prochilod from brackish environments is needed to support management decisions about this resource. The studies of capture, tagging and recapture have provided interesting information about brackish incursions. However, these studies have not been able to determine the proportion of individuals using the estuary, and the ages at which brackish environment use occurred. For example, Espinach Ros et al. (1998) have reported displacements of up to $1,100 \mathrm{~km}$ for fish tagged in the Uruguay River and recaptured in the Paraná, as well as movements between Uruguay River and the La Plata Estuary. It has also been reported a tagged specimen in Buenos Aires City (near the limit of the estuary), which was recaptured 1,500 km upstream in the Paraná River (Sverlij et al., 1993). It seems that there is an important connectivity between groups of fish from Paraná and Uruguay rivers with the estuary.

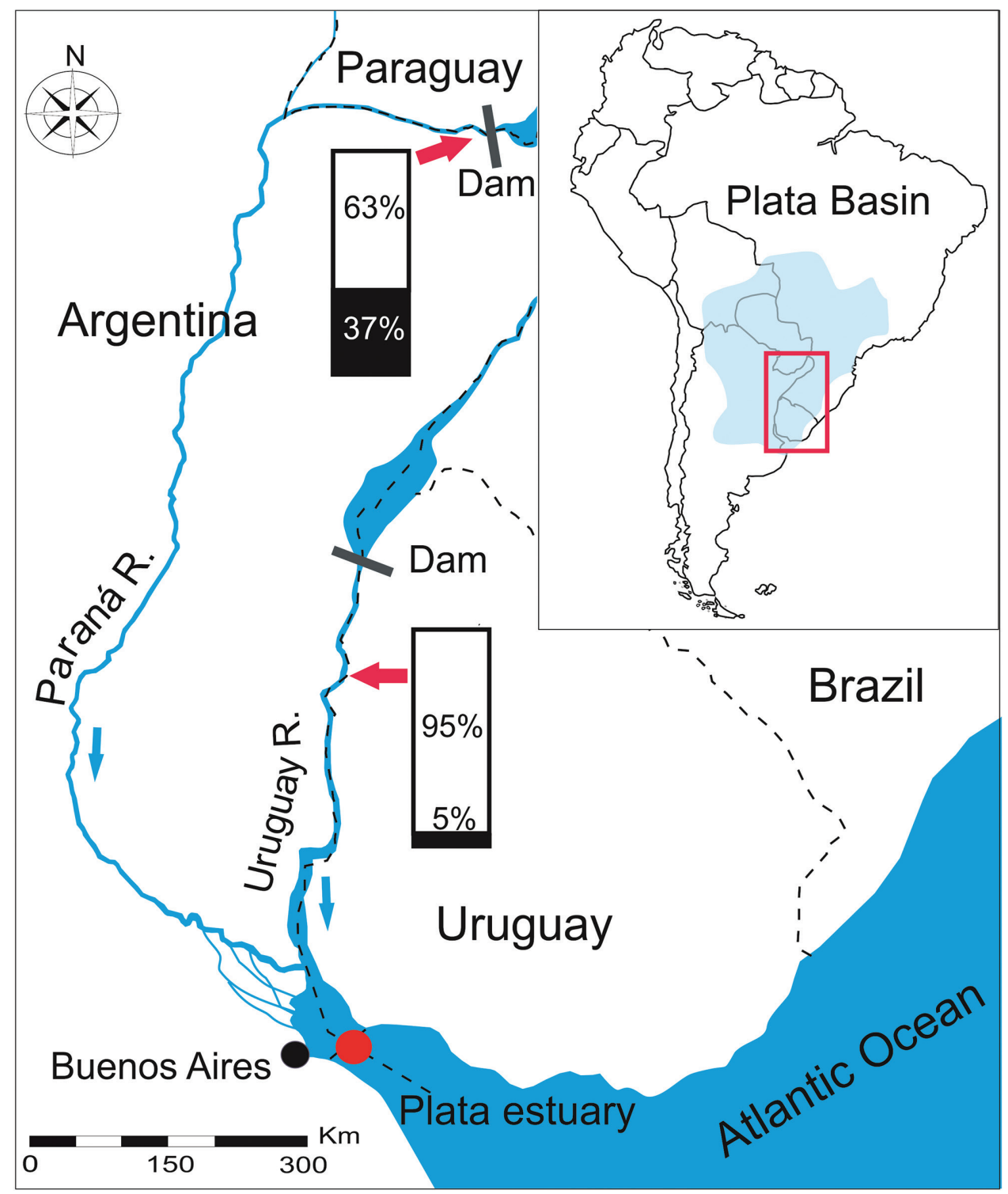

Fig. 1. Sampling sites of Prochilodus lineatus (red arrows). Red point shows the sampling site of fish use for transition threshold estimation between freshwater and brackish environments. The bar charts show the proportion of each migratory pattern for each collection site (black: freshwater straggler; white, freshwater resident). 
Tagging studies result extremely expensive due to the extension of the basin and the number of specimens needed to be tagged to obtain a representative number of recaptures (Begg, Waldman, 1999). In the past two decades, the chemical composition of fish otoliths has been developed as a natural tracer of habitat use and cost-effective alternative to mark recapture investigations. Otoliths are structures composed mainly of calcium carbonate deposited as aragonite, vaterite or calcite crystals in a protein matrix (otoline) found in the inner ear (Campana et al., 1997). Chemical composition is preserved in the otolith chronology because deposited material is not reabsorbed or altered (Campana, Neilson, 1985; Casselman, 1990; Campana, Thorrold, 2001; Elsdon et al., 2008). Trace elements in combination with growth rings result in an important file that records environment information experienced by fish, environmental changes and exposure to pollutants throughout ontogeny (Halden, Friedrich, 2008). Because many cationic trace elements substitute for calcium in the otolith chemical matrix, element ratio, such as $\mathrm{Sr}: \mathrm{Ca}$, (rather than single element concentrations) provide the most accurate representation of chemical gradients in the water (Bath et al., 2000). In estuaries, salinity often has a positive correlation with otolith $\mathrm{Sr}: \mathrm{Ca}$ when the freshwater end-member has lower $\mathrm{Sr}: \mathrm{Ca}$ than sea-water (Secor, Rooker, 2000; Kraus, Secor, 2004; Martin et al., 2004; Sturrock et al., 2012). The techniques used to study ontogenetic changes of Sr:Ca ratio in otoliths include spot and line scan analysis by electron probe microanalysis (EPMA), microproton-induced X-ray emission (micro-PIXE) (Lin et al., 2007; Hedger et al., 2008; Daros et al., 2016), and more recently laser ablation-inductively coupled plasma-mass spectrometry (LA-ICP-MS) (MoralesNin et al., 2014; Fowler et al., 2016; Kissinger et al., 2016; Avigliano et al., 2017b; Callicó Fortunato et al., 2017).

Considering the lack of knowledge about the use of environments with different salinities, our objective was to analyze brackish environment use by the streaked prochilod captured from the La Plata Basin (Paraná and Uruguay rivers). In particular, we evaluated the proportion of individuals using the estuary, and the ages at which brackish environment use occurred. We accomplished this by analyzing transects of $\mathrm{Sr}: \mathrm{Ca}$ in lapilli sections using LA-ICP-MS.

\section{Material and Methods}

Sample collection. Fish were collected between February 2011 and November 2014 by using trammel nets in the Uruguay River, $\left(31^{\circ} 25.246\right.$ 'S-58 $8^{\circ} 1.407^{\prime} \mathrm{W}-31^{\circ} 59.105^{\prime} \mathrm{S}-$ $58^{\circ} 9.599^{\prime} \mathrm{W}$ ) (Corrientes and Entre Ríos provinces, Argentina-Uruguay international boundary) and in the Paraná River $\left(27^{\circ} 25.467^{\prime} \mathrm{S}-58^{\circ} 48.133^{\prime} \mathrm{W}\right)$ (Corrientes province, Argentina-Paraguay international boundary) (Fig. 1). Additionally, 9 adult fish were collected at the boundary between freshwater and the estuary $\left(34^{\circ}\right.$ 41.969'S- 57 $40.291^{\prime} \mathrm{W}$ ) (inner parts of the La Plata Estuary, salinity $\geq 0.5$ PSU).
Once the nets were recovered, the fish were killed with percussive stunning (Van De Vis et al., 2003). Fish were placed on ice and transported to the laboratory where they were measured (standard length=SL) and the lapilli otoliths were extracted. We preferred using lapilli otoliths rather than sagittae or asterisci otoliths because they were larger and allowed less measurement error (Assis, 2005; Avigliano et al., 2015a).

Otoliths from Uruguay River and La Plata estuary were deposited in the collection of the Continental Fishing Laboratory of the Ministry of Agro-industry from Buenos Aires, Argentina (vouchers numbers: 124579-131140) while Paraná River otoliths were deposited in the National University of the Northeast, Corrientes, Argentina (vouchers numbers: 2011/1-2011/223, 2013/7-2013318, 2014/3-2014/33).

Age determination and otolith preparation. Otoliths were weighed using a Sartorius AG ED 2242 (Göttingen, Germany) analytical balance, washed with Milli-Q water with a resistivity of $18.2 \mathrm{~m} \Omega / \mathrm{cm}$ and dried. The left otolith of each pair was embedded in epoxy resin and sectioned transversely through the core to a thickness of $700 \mu \mathrm{m}$ using a Buehler Isomet low speed saw (Hong Kong, China) equipped with twin diamond edge blades and spacers. The number of annuli in the otolith section was counted with the piece immersed in ultrapure water, using a stereomicroscope (Leica EZ4-HD, Singapore) at 40X magnification. Age estimation by counting the annuli in lapilli otoliths of $P$. lineatus was validated by Espinach Ros et al. (2008). To avoid age effect on otolith chemistry, only fish between 1215 years were selected for analysis (21 for Uruguay River and 30 for Paraná River) (Tab. 1).

Tab. 1. Descriptive statistics of individuals from each sampling site. N: sample size; SD: standard deviation.

\begin{tabular}{|c|c|c|c|c|c|c|c|}
\hline \multirow[b]{3}{*}{ Uruguay River } & \multicolumn{3}{|c|}{ Age (year) } & \multicolumn{3}{|c|}{ Standard length $(\mathrm{cm})$} & \multirow[t]{2}{*}{$\mathrm{N}$} \\
\hline & \multicolumn{2}{|c|}{ mean $\pm \mathrm{SD}$} & \multirow{2}{*}{$\begin{array}{l}\text { range } \\
12-15\end{array}$} & \multicolumn{2}{|c|}{ mean $\pm \mathrm{SD}$} & \multirow{2}{*}{$\frac{\text { range }}{46-54}$} & \\
\hline & 13.8 & 0.9 & & 46.3 & 3.4 & & 21 \\
\hline Paraná River & 14.0 & 1.3 & $12-15$ & 43.8 & 5.6 & $36-58$ & 30 \\
\hline
\end{tabular}

Otolith sections were fixed to glass slides using clear epoxy resin. In addition, the potential exists of vateritic inclusions was evaluated by observed under reflected light after EDTA etching (Tzeng et al., 2007). Otolith sections were rinsing 3 times in Milli-Q water and drying in a laminar flow hood.

Determination of Sr:Ca ratio by LA-ICP-MS analysis. Laser Ablation Inductively Coupled Plasma Mass Spectrometry (LA-ICPMS) analyses were conducted at University of Oviedo, Spain, using a $193 \mathrm{~nm} \mathrm{ArF}^{*}$ Excimer laser ablation system (Photon Machines Analyte G2) coupled to an ICP-MS Agilent 7700 (Agilent Technologies, Santa Clara, USA). Analytical conditions of the LA-ICPMS system are summarized in Tab. 2. 
Tab. 2. LA-ICPMS operating conditions.

\begin{tabular}{lll}
\hline Instrument & Parameter & Value \\
\hline ArF 193nm laser ablation & & \\
& Laser fluence & $12 \mathrm{~J} / \mathrm{cm}^{2}$ \\
& Repetition rate & $10 \mathrm{~Hz}$ \\
& Pitsize diameter & $30 \mu \mathrm{m}$ \\
& Ablation Cell & Two-volume HelEx cell \\
& Cell gas Flow & $\mathrm{He}-0.81 / \mathrm{min}$ \\
& Scan Speed & $5 \mu \mathrm{m} / \mathrm{s}$ \\
& & \\
ICP-QMS & Acquisition mode & $\mathrm{Time} \mathrm{resolved}$ \\
& Nebulizer gas flow & $\mathrm{Ar}-0.9 \mathrm{l} / \mathrm{min}$ \\
& Isotopes measured & ${ }^{43} \mathrm{Ca}$ and ${ }^{88} \mathrm{Sr}$ \\
& Integration time & $210 \mathrm{~ms} /$ isotope \\
\hline
\end{tabular}

Helium was used as the carrier gas in the ablation cell and Ar was added before entering the ICP. The ion optics were adjusted to yield maximum sensitivity and balanced mass response while ablating National Institute of Standards and Technology standard reference material SRM NIST 612 glass. The optimization was carried out manually while monitoring ${ }^{7} \mathrm{Li}^{+},{ }^{133} \mathrm{Cs}^{+},{ }^{232} \mathrm{Th}^{+},{ }^{238} \mathrm{U}^{+}$ and ${ }^{232} \mathrm{Th}^{16} \mathrm{O}^{+}$ion signal intensities. Plasma robustness was monitored via the ${ }^{232} \mathrm{Th}^{16} \mathrm{O} /{ }^{232} \mathrm{Th}$ and the ${ }^{238} \mathrm{U} / 232 \mathrm{Th}$ intensity ratios. $\mathrm{ThO}^{+} / \mathrm{Th}^{+}$intensity ratios were always below $0.4 \%$ and ${ }^{238} \mathrm{U}^{+} 232 \mathrm{Th}^{+}$intensity ratio was less than 1.2 . Additionally, the cross calibration of the pulse and analogue stages of the scanning electron microscope detector ("PA-factor") was carried out daily to ensure a linear response of the instrument of $>8$ orders of magnitude for the isotopes of interest.

NIST SRM 612 silicate glass reference material was employed as an external reference material (Pearce et al., 1997; Jochum et al., 2011; NIST, 2012) to quantify the concentration of $\mathrm{Sr}$, using a fixed value for $\mathrm{Ca}$ as an internal standard. Calcium concentration of the otolith matrix was assumed to be 38.8 wt.\% (Yoshinaga et al., 2000 ; Hamer et al., 2015). In particular, ion signals from ${ }^{43} \mathrm{Ca}^{+}$and ${ }^{88} \mathrm{Sr}^{+}$were measured in the otoliths and in NIST 612, using the laser ablation scan mode (transects). Ion signals were collected before the ablation process to determine their background level and during the ablation process. Net ion signals were employed in the bracketing quantification method, where the reference material (NIST 612) is analysed at the beginning and at the end of each analysis session to monitor and correct for any signal drift. The maximum deviation observed during one analytical session was about $5 \%$. For instance, the average concentration of $\mathrm{Sr}$ measured in NIST 612 during the analytical session was $78 \pm 4 \mathrm{ppm}$, which is in good agreement with the nominal value of $78.4 \pm 0.2 \mathrm{ppm}$ (NIST, 2012). The limit of detection (LOD) for Sr was $0.0023 \mathrm{mmol} /$ mol, calculated using the 3 sigma criteria. Concentration of $\mathrm{Sr}$ was expressed as molar ratios (element: $\mathrm{Ca}=\mathrm{mmol} / \mathrm{mol}$ ) to account for fluctuations in the amount of material analyzed and the loss of material during the preparation process (Sinclair et al., 1998; Bailey et al., 2015).
Pattern classification and data analysis. Similar to Albuquerque et al. (2010), Sr:Ca ratio of the otolith edge (last spot of the transect) was compared among sampling sites using Kruskal Wallis test, in order to evaluate whether there is coherence with the capture sites (Uruguay and Paraná Rivers and La Plata Estuary) and the salinity associated with them (a higher $\mathrm{Sr}: \mathrm{Ca}$ ratio is expected near the estuary). Data were tested for normality and homogeneity of variance using the Shapiro-Wilk and Levene's tests respectively. Prior to Kruskal Wallis test, we evaluated the association between the $\mathrm{Sr}: \mathrm{Ca}$ ratio of the otolith edge and the fish age using Spearman correlation. The existence of a correlation with the age could affect the interpretation of the Sr:Ca ratio.

To facilitate the interpretation of transects, the threshold that represents the transition between the freshwater environment and the estuary was calculated using the $\mathrm{Sr}: \mathrm{Ca}$ ratio of the edge of the otolith (last spot of the transect) of 9 additional specimens captured in the first section of the $\mathrm{La}$ Plata estuary (salinity $\geq 0.5$ PSU) (Fig. 1). The threshold was estimated as the average of $\mathrm{Sr}: \mathrm{Ca}$ ratio of the otolith edge plus twice the standard deviation (mean $+2 * \mathrm{SD})$ as suggested by Lin et al. (2015) and Avigliano et al. (2017b).

Several algorithms have been used to facilitate the interpretation of fish movement patterns and to quantify the number of habitat changes during their life history (Hedger et al., 2008; Walther et al., 2011; Killick, Eckley, 2014; Freshwater et al., 2015; Hegg et al., 2015; Wynne et al., 2015). In this work we used Change-Point analysis (CPA) to facilitate the classification of individuals and quantify the number of changes in otolith elemental ratio (Shrimpton et al., 2014; Hegg et al., 2015). We assumed that significant changes in the transect corresponded with habitat changes due to chemical composition of the water (Freshwater et al., 2015; Hegg et al., 2015; Wynne et al., 2015). CPA determined whether there had been a change in the underlying process that generated the sequence of events and identified where the change occurred. The procedure used to perform a CPA comprises a combination of cumulative sum charts and boot strapping to identify shifts in the pattern of $\mathrm{Sr}: \mathrm{Ca}$. The analysis provides both confidence levels and confidence intervals for each change ( $95 \%$ confidence is used for all confidence intervals) and it is robust to issues of non-normality (Shrimpton et al., 2014). The Change-Point Analyzer 2.3 software package (Taylor, 2000) was used for CPA.

Transects, thresholds and change points in the $\mathrm{Sr}: \mathrm{Ca}$ chronologies were graphically inspected to infer movement between freshwater and brackish environments (Wynne et al., 2015).

In this work, patterns were defined based on habitat use assuming an approach similar to that of Elliott et al. (2007) as follows (Fig. 2): 1) freshwater resident: defined as permanence in freshwater throughout life and 2) freshwater straggler: defined as freshwater fish found in estuaries in low number and whose distribution is usually limited to the low salinity in upper reaches of estuaries. 

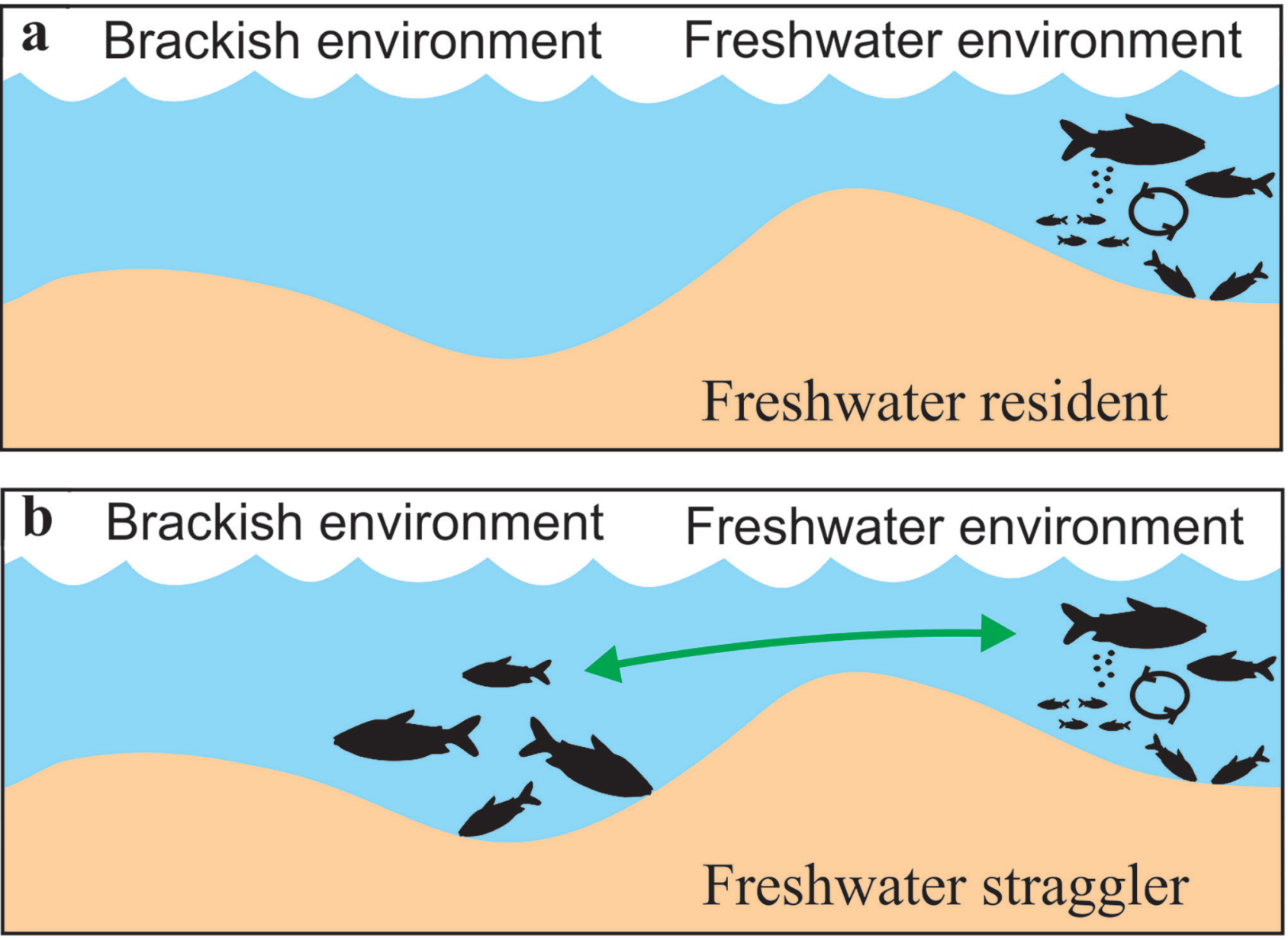

Fig. 2. Habitat use patters according to Elliott et al. (2007). a. freshwater resident and b. freshwater straggler. Modified from the fig. 1 of Potter et al. (2015).

Following Walther et al. (2011) and Shrimpton et al. (2014), the variable "number of changes" was compared between locations (Uruguay and Paraná rivers) using the non-parametric Mann-Whitney U test because the response was not normally distributed with heterogeneous variance (Shapiro-Wilk, $\mathrm{p}<0.05$; Levene, $\mathrm{p}<0.05$ ), even after transformation $\log (\mathrm{x}+1)$. Prior to parametric Mann-Whitney $\mathrm{U}$ test, we evaluated the association between the number of $\mathrm{Sr}: \mathrm{Ca}$ changes and the fish age using Spearman correlation.

\section{Results}

Otolith edge and threshold estimation. Otolith edge had Sr:Ca values of $1.19 \pm 0.22,1.33 \pm 0.33$ and $1.66 \pm 0.22$ $\mathrm{mmol} / \mathrm{mol}$ for the Uruguay and Paraná Rivers and Estuary, respectively (Fig. 3), being significantly higher for the latter $(\mathrm{H}=13.3, \mathrm{p}<0.009)$. No correlation was found between age and $\mathrm{Sr}: \mathrm{Ca}(\mathrm{r}=-0.24, \mathrm{p}=0.1)$. For this reason, it was not necessary to make age corrections in variables.

A reference value for movements between freshwater and brackish environments was calculated as the average $\mathrm{Sr}: \mathrm{Ca}$ value $+2 * \mathrm{SD}(1.66 \mathrm{mmol} / \mathrm{mol}+2 * 0.22=2.12 \mathrm{mmol} / \mathrm{mol})$ at the otolith edge of 9 specimens caught in the first section of the estuary (Fig. 1). Values greater than the $\mathrm{Sr}: \mathrm{Ca}=2.12$ $\mathrm{mmol} / \mathrm{mol}$ threshold were considered indicative of brackish environment use.

Otolith microchemical profiles of specimens caught in the estuary are shown in the complementary figure $\mathbf{S 1}$ Available only as online supplementary file accessed with the online version of the article at http://www.scielo.br/ni.

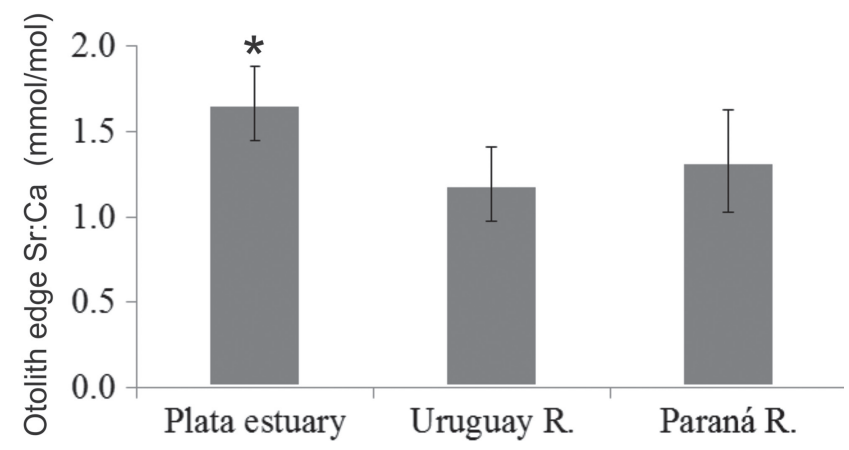

Fig. 3. Otolith edge Sr:Ca ratio of Prochilodus lineatus calculated for freshwater and brackish environments. Asterisks indicate a statistically significant $(\mathrm{p}<0.05)$ difference between sampling sites. 
Life history and migration patterns allocation. Considering the fish captured in fresh water, the otolith Sr:Ca ratio ranged between 0.34 and $3.19 \mathrm{mmol} / \mathrm{mol}$ (mean $\pm \mathrm{SD}: 1.33 \pm 0.33 \mathrm{mmol} / \mathrm{mol})$. Fish had values of $\mathrm{Sr}: \mathrm{Ca}$ in the otolith core and edge that were less than the reference value, suggesting that these were hatched and caught in freshwater environments (Fig. 4).

The percentage of each migratory behavior is represented as a percentage in bar charts for each sampling site (Fig. 1). Freshwater resident pattern was observed in 95\% ( $\mathrm{N}=20)$ and $63 \%(\mathrm{~N}=19)$ while, freshwater straggler was found $5 \%(\mathrm{~N}=1)$ and $37 \%(\mathrm{~N}=11)$ in Uruguay and Paraná Rivers, respectively (Fig. 1).

According to the results of the CPA and the estimated threshold, clear patterns were not observed in relation to the ages at which the brackish incursions occur (Fig. 4). Of all fish classified as freshwater straggler, $46.4 \%$ were predicted to make brackish incursions between age- 3 and age-5. Only $30.6 \%$ of freshwater straggler specimens were predicted to enter the estuary more than once.

Specifically, the only freshwater straggler specimen captured in the Uruguay River performed only one brackish incursion at the age of 5 (Fig. 4f).

Among the 11 freshwater straggler fish caught in the Paraná, 4 performed a single incursion between the $3 \mathrm{rd}$ and the 4 th year of life. Three other specimens performed a single incursion at the ages of 1,8 and 14 years respectively. Finally, 4 specimens performed between 3 and 4 incursions at the ages of 12 and 13;1, 2 and 4; $0^{+}, 7$ and 11;2, 10-12 and 15 years, respectively (Fig. 4b-c).

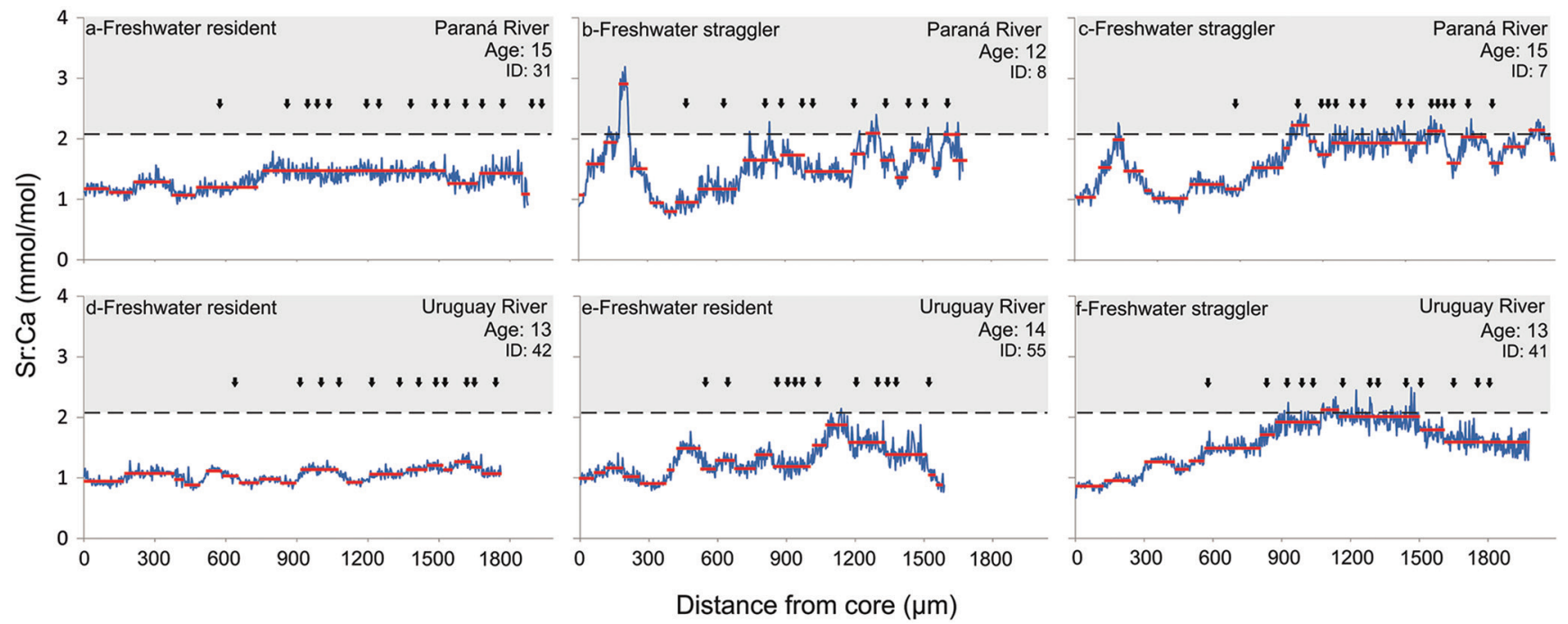

Fig. 4. Otolith microchemical profiles of Prochilodus lineatus from core to edge (age: 12-15). Vertical arrows indicate otolith annuli (age) and black dashed line indicate upper (brackish) and lower (freshwater) thresholds for Sr:Ca. Horizontal lines illustrate stable signatures identified by using change-point analysis for the Sr:Ca ratio.

Quantification of changes in the life history. The global average (mean \pm SD) for the number of changes of environment (or change points per transect) was $20.5 \pm$ 5.4 (range: 9-33). Number of changes in transects of $\mathrm{Sr}: \mathrm{Ca}$ were $18.5 \pm 5.3$ and $22.5 \pm 5.6$ for Uruguay and Paraná Rivers, respectively.

Spearman test showed that there is no correlation between age and number of changes points $(r=-0.25$, $p=0.08)$. The Mann-Whitney $U$ test showed significant differences in the number of changes in transects of $\mathrm{Sr}: \mathrm{Ca}$ between sampling sites $(U=810, p=0.0001)$, being higher in the Paraná River.

\section{Discussion}

While transition thresholds between environments seem to vary among teleost fish, our threshold estimate for brackish environment use ( $\mathrm{Sr}: \mathrm{Ca}=2.12 \mathrm{mmol} / \mathrm{mol})$ was comparable to benchmarks for other species. For example,
Bradbury et al. (2008) has reported values $\sim 2.3 \mathrm{mmol} / \mathrm{mol}$ for Osmerus mordax (Mitchill, 1814) while Smith, Kwak (2014) reported values of $\sim 3 \mathrm{mmol} / \mathrm{mol}$ for Gobiomorus dormitor Lacepède, 1800. However, euryhaline species were associated with significantly higher values of reference, as Mugil cephalus Linnaeus, 1758 ( $\mathrm{Sr}: \mathrm{Ca}=3.3 \mathrm{mmol} / \mathrm{mol})$ (Fowler et al., 2016), Genidens barbus (Lacepède, 1803) (Sr:Ca=3.75 mmol/mol) (Avigliano et al., 2017b) and Zenarchopterus dunckeri Mohr, 1926 (Sr:Ca=4.2 mmol/ mol for freshwater-brackish) (Kanai et al., 2014).

Low La Plata Basin has a salinity gradient in north-south direction, which is positively correlated with $\mathrm{Sr}$ :Ca ratio of water (Avigliano, Volpedo, 2013). For this reason, the Sr:Ca ratio of otolith has been widely used to infer migratory and population aspects of several species (Avigliano, Volpedo, 2016); for example Genidens barbus (Avigliano et al., 2015a,b, 2016a, 2017b), Odontesthes bonariensis (Valenciennes, 1835) (Avigliano, Volpedo, 2013; Avigliano et al., 2014, 2015c), Mugil liza Valenciennes, 1836 
(Callicó Fortunato et al., 2017), Lycengraulis grossidens (Spix \& Agassiz, 1829) (Mai et al., 2014), Micropogonias furnieri (Desmarest, 1823) (Albuquerque et al., 2012) and P. lineatus (Avigliano et al., 2016b, 2017a). Particularly in $P$. lineatus it has been used the otolith microchemistry ( $\mathrm{Sr}: \mathrm{Ca}, \mathrm{Ba}: \mathrm{Ca}$ and $\mathrm{Zn}: \mathrm{Ca}$ ratios) as well as otolith and scales morphometry in order to identify different nursery areas (Avigliano et al., 2016b, 2017a). According to Avigliano et al. (2017) the capture sites studied in this work are also different nursery areas. In contrast to previous publications on the species, this paper describes for the first time details on brackish use, revealing that a considerable proportion of fish from Paraná River, depending on the sampling site, uses this environment throughout his life.

Other methodologies have been used to study migratory and biological aspects of the streaked prochilod, primarily tagging and recapture (Bonetto et al., 1981; Delfino, Baigun, 1985; Sverlij et al., 1993; Espinach Ros et al., 1998) although biochemical methods (Colombo et al., 2011; Speranza et al., 2012) and distribution studies (Bayley, 1973; Stassen et al., 2012) have also been conducted. These studies show brackish use in some specimens, but also suggested the presence of non-migratory fish, especially in the Uruguay River (Bonetto et al., 1981; Delfino, Baigun, 1985; Espinach Ros et al., 1998). Our results provide further evidence of this connectivity and revealed that streaked prolichod in the estuary utilize this habitat intermittently throughout their lives. Espinach Ros et al. (1998) have also reported the existence of adult specimens that did not migrate (evaluated period of 3 years) with respect to the place tagged on the Uruguay River, suggesting the existence of resident populations. In this work, the highest percentage of freshwater resident specimens was registered in the Uruguay River. However, it is not possible to affirm that these specimens are not migratory, as they could move long distances among environments with similar salinity and make no significant differences in Sr:Ca ratio of otolith (Avigliano et al., 2017a).

According to CPA, the greatest number of changes was observed for the Paraná River, which is consistent with the highest percentage of freshwater stragglers specimens (Fig. 1).

It is clear that the use of environments with different salinities is complex and highly variable between sites and specimens. In this sense, the variability in the observed migration patterns could be associated with different evolutionary adaptations (Lucas, Baras, 2001; McDowall, 2001; Elliott et al., 2007). Brackish incursions could also facilitate connectivity between the great rivers. This way fish could move into new environments and perhaps into more beneficial ones in terms of food and reproduction, especially if the natal site had changed.

Our results are important for the management of the shad resource. Even though there are bi-national organisms that monitor the resource (Comisión Administradora del Río Uruguay, CARU), there is no management of it at a basin or sub-basin level. Even integral management is not carried out within some countries. For example, in Argentina each province has independent regulations and handle closed seasons, minimum catch sizes and different fishing quotas. Even Buenos Aires province (Argentina) has banned the fishing and commercialization of shad caught in the Río de la Plata since 2000 (SAP, 2000) due to the presence of contaminants found in muscle and in the estuary. It has been suggested that shad may transport dozens of tons of contaminants per year from the estuary to the Paraná and Uruguay rivers (Colombo et al., 2011). The results of the present study allow inferring that a proportion of the shads captured in the middle portion of the Uruguay and Paraná rivers use the estuary in different stages of its life. In this sense, the possibility of implementing regulations at the regional level, rather than local, should be discussed. Considering the use of brackish waters and migration distances, other methods of assessment and management should be considered in order to ensure not only the sustainability of the fishery but also the quality of the product for consumption. Management methods should consider connectivity between different points in the basin, paying special attention to brackish use by the species, since this could affect the quality of the meat and affect consumer health (Colombo et al., 2011; Speranza et al., 2012).

In conclusion, although it is known that streaked prochilod performs upstream migrations in winter for reproduction and downstream migration in summer to feed (Sverlij et al., 1993), occupation of brackish environments is highly variable among individuals with unknown consequences at the population level. Excessive commercial fishing may have rapid negative effects on resident populations. In this sense, populations should be managed integrally. Here, we have to emphasize the need to link the obtained results with current resource management actions in order to contribute to their sustainability. We highlight the importance of intensifying this type of studies including other markers such as stable isotopes of $\mathrm{Sr}$, which would allow to track the movements of the specimens in freshwater throughout the basin (Hegg et al., 2015).

\section{Acknowledgments}

Authors thank to CONICET (PIP112-20120100543CO), Universidad de Buenos Aires, ANPCYT (PICT 2010132), Entidad Binacional Yacyretá and Administrative Commission of the River Uruguay (CARU), for financial and logistic support. J. In the Uruguay River, samples were taken in the framework of the activity "Survey Ichthyofauna Uruguay River" which is included within the program "Wildlife Conservation and Fishery Resources" (CARU). Pisonero would like to acknowledge the financial support from the Government of the Principality of Asturias through the project FC-15-GRUPIN14-040. We thank the Editor and anonymous reviewers for their constructive comments, which helped us to improve the manuscript. 


\section{References}

Albuquerque CQ, Miekeley N, Muelbert JH. White mouth croaker, Micropogonias furnieri, trapped in a freshwater coastal lagoon: a natural comparison of freshwater and marine influences on otolith chemistry. Neotrop Ichthyol. 2010; 8(2):311-20.

Albuquerque CQ, Miekeley N, Muelbert JH, Walther BD, Jaureguizar AJ. Estuarine dependency in a marine fish evaluated with otolith chemistry. Mar Biol. 2012; 159(10):2229-39.

Assis CA. The utricular otoliths, lapilli, of teleosts: their morphology and relevance for species identification and systematics studies. Sci Mar. 2005; 69(2):259-73.

Avigliano E, Volpedo AV. Use of otolith strontium:calcium ratio as an indicator of seasonal displacements of the silverside (Odontesthes bonariensis) in a freshwater-marine environment. Mar Freshw Res. 2013; 64(8):746-51.

Avigliano E, Carvalho B, Velasco G, Tripodi P, Vianna M, Volpedo AV. Nursery areas and connectivity of the adults anadromous catfish (Genidens barbus) revealed by otolith core microchemistry in the southwestern Atlantic Ocean. Mar Freshw Res. 2016a; 68(5): 931-940.

Avigliano E, Domanico A, Sánchez S, Volpedo AV. Otolith elemental fingerprint and scale and otolith morphometry in Prochilodus lineatus provide identification of natal nurseries. Fish Res. 2017a; 186(1):1-10.

Avigliano E, Fortunato RC, Biolé F, Domanico A, Simone S De, Neiff JJ, et al. Identification of nurseries areas of Juvenile Prochilodus lienatus (Valenciennes, 1836) by scale and otolith morphometry and microchemistry. Neotrop Ichthyol. 2016b; 14(3):e160005.

Avigliano E, Leisen M, Romero R, Carvalho B, Velasco G, Vianna $\mathrm{M}$, et al. Fluvio-marine travelers from South America: cyclic amphidromy and freshwater residency, typical behaviors in Genidens barbus inferred by otolith chemistry. Fish Res. 2017b; 193:184-94.

Avigliano E, Martinez CFR, Volpedo AV. Combined use of otolith microchemistry and morphometry as indicators of the habitat of the silverside (Odontesthes bonariensis) in a freshwaterestuarine environment. Fish Res. 2014; 149:55-60.

Avigliano E, Velasco G, Volpedo AV. Use of lapillus otolith microchemistry as an indicator of the habitat of Genidens barbus from different estuarine environments in the southwestern Atlantic Ocean. Environ Biol Fish. 2015a; 98(6):1623-32.

Avigliano E, Velasco G, Volpedo AV. Assessing the use of two southwestern Atlantic estuaries by different life cycle stages of the anadromous catfish Genidens barbus (Lacépède, 1803) as revealed by $\mathrm{Sr}: \mathrm{Ca}$ and $\mathrm{Ba}: \mathrm{Ca}$ ratios in otoliths. J Appl Ichthyol. 2015b; 31(4):740-43.

Avigliano E, Villatarco P, Volpedo AV. Otolith Sr:Ca ratio and morphometry as indicators of habitat of a euryhaline species: The case of the silverside Odontesthes bonariensis. Ciencias Mar. 2015c; 41(3):189-202.

Avigliano E, Volpedo AV. A review of the application of otolith microchemistry toward the study of Latin American fishes. Rev Fish Sci Aquac. 2016; 24(4):369-84.
Bailey DS, Fairchild EA, Kalnejais LH. Microchemical signatures in juvenile winter flounder otoliths provide identification of natal nurseries. Trans Am Fish Soc. 2015; 144(1):173-83.

Bath GE, Thorrold SR, Jones CM, Campana SE, McLaren JW, Lam JWH. Strontium and barium uptake in aragonitic otoliths of marine fish. Geochim Cosmochim Acta. 2000; 64(10):1705-14.

Bayley PB. Studies on the migratory characin, Prochilodus platensis Holmberg 1889, (Pisces, Characoidei) in the River Pilcomayo, South America. J Fish Biol. 1973; 5(1):25-40.

Begg GA, Waldman JR. An holistic approach to fish stock identification. Fish Res. 1999; 43(1-3):35-44.

Bonetto AA, Canon Veron M, Roldán D. Nuevos aportes al conocimiento de las migraciones de peces en el río Paraná. Ecosur. 1981; 8(16):29-40.

Bradbury IR, Campana SE, Bentzen P. Otolith elemental composition and adult tagging reveal spawning site fidelity and estuarine dependency in rainbow smelt. Mar Ecol Prog Ser. 2008; 368:255-68

Callicó Fortunato R, González-Castro M, Galán AR, Alonso IG, Kunert C, Durà VB, et al. Identification of potential fish stocks and lifetime movement patterns of Mugil liza Valenciennes 1836 in the Southwestern Atlantic Ocean. Fish Res. 2017; 193:164-72.

Campana SE, Neilson JD. Microstructure of fish otoliths. Can J Fish Aquat Sci. 1985; 42(5):1014-1032.

Campana SE, Thorrold SR. Otoliths, increments, and elements: keys to a comprehensive understanding of fish populations? Can J Fish Aquat Sci. 2001; 58(1):30-38.

Campana SE, Thorrold SR, Jones CM, Günther D, Tubrett M, Longerich $\mathrm{H}$, et al. Comparison of accuracy, precision, and sensitivity in elemental assays of fish otoliths using the electron microprobe, proton-induced X-ray emission, and laser ablation inductively coupled plasma mass spectrometry. Can J Fish Aquat Sci. 1997; 54(9):2068-79.

Casselman JM. Growth and relative size of calcified structures of fish. Trans Am Fish Soc. 1990; 119(4):673-88.

Colombo JC, Cappelletti N, Williamson M, Migoya MC, Speranza E, Sericano J, et al. Risk ranking of multiple-POPs in detritivorous fish from the Río de la Plata. Chemosphere. 2011; 83(6):882-89.

Daros FA, Spach HL, Correia AT. Habitat residency and movement patterns of Centropomus parallelus juveniles in a subtropical estuarine complex. J Fish Biol. 2016; 88(5):1796-810.

Delfino R, Baigún C. Marcaciones de peces en el embalse de salto Grande, Rio Uruguay (Argentina - Uruguay). Rev Asoc Cienc Nat Litoral. 1985; 16(1):85-93.

Elliott M, Whitfield AK, Potter IC, Blaber SJM, Cyrus DP, Nordlie FG, et al. The guild approach to categorizing estuarine fish assemblages: a global review. Fish Fish. 2007; 8(3):241-68.

Elsdon TS, Wells BK, Campana SE, Gillanders BM, Jones CM, Limburg KE, et al. Otolith chemestry to describe movements and life-history parameters of fish: hypotheses, assumptions, limitations and inferences. Oceanogr Mar Biol. 2008; 46:297-330. 
Espinach Ros A, Demonte LD, Campana M, Trogolo A, Dománico A, Cordiviola E. Estimación de edades y crecimiento. Evaluación Del Recurso Sábalo (Prochilodus Lineatus) en el Río Paraná. Informe de los resultados de la segunda etapa 2006-2007. Buenos Aires: Secretaría de Ganadería, Pesca y Alimentos; Subsecretaría de Pesca y Acuicultura; 2008. Available from: http:/www.agroindustria.gob.ar/sitio/areas/ pesca_continental/informes/baja/index.php

Espinach Ros A, Sverlij S, Amestoy F, Spinetti M. Migration pattern of the sábalo Prochilodus lineatus (Pisces, Prochilodontidae) tagged in the lower Uruguay River. Verhandlung Int Verein Limnol. 1998; 22:2234-36.

Fowler AM, Smith S, Booth DJ, Stewart J. Partial migration of grey mullet (Mugil cephalus) on Australia's east coast revealed by otolith chemistry. Mar Environ Res. 2016; 119:238-44.

Freshwater C, Trudel M, Beacham TD, Neville C-E, Tucker S, Juanes F. Validation of daily increments and a marine-entry check in the otoliths of sockeye salmon Oncorhynchus nerka post-smolts. J Fish Biol. 2015; 87(1):169-78.

Guerrero RA, Acha EM, Framiñan MB, Lasta CA. Physical oceanography of the Río de la Plata Estuary, Argentina. Cont Shelf Res. 1997; 17(7):727-42.

Halden NM, Friedrich LA. Trace-element distributions in fish otoliths: natural markers of life histories, environmental conditions and exposure to tailings effluence. Mineral Mag. 2008; 72(2):593-605.

Hamer P, Henderson A, Hutchison M, Kemp J, Green C, Feutry P. Atypical correlation of otolith strontium : Calcium and barium : calcium across a marine-freshwater life history transition of a diadromous fish. Mar Freshw Res. 2015; 66(5):411-19.

Hedger RD, Atkinson PM, Thibault I, Dodson JJ. A quantitative approach for classifying fish otolith strontium: Calcium sequences into environmental histories. Ecol Inform. 2008; 3(3):207-17.

Hegg JC, Giarrizzo T, Kennedy BP. Diverse early life-history strategies in migratory Amazonian catfish: Implications for conservation and management PLoS One. 2015; 10(7):e0129697.

Jochum KP, Weis U, Stoll B, Kuzmin D, Yang Q, Raczek I, et al. Determination of reference values for NIST SRM 610-617 glasses following ISO guidelines. Geostand Geoanal Res. 2011; 35(4):397-429.

Kanai T, Nanjo K, Yamane K, Amano Y, Kohno H, Watanabe Y, et al. Utilization patterns of estuarine and marine habitats by the halfbeak Zenarchopterus dunckeri at Iriomote Island, southern Japan, evaluated from otolith microchemistry. Fish Sci. 2014; 80(6):1231-39.

Killick R, Eckley IA. Changepoint: An R Package for changepoint analysis. J Stat Soft. 2014; 58(3):1-15.

Kissinger BC, Gantner N, Anderson WG, Gillis DM, Halden NM, Harwood LA, et al. Brackish-water residency and semi-anadromy in Arctic lake trout (Salvelinus namaycush) inferred from otolith microchemistry. J Great Lakes Res. 2016; 42(2):267-75.

Kraus RT, Secor DH. Incorporation of strontium into otoliths of an estuarine fish. J Exp Mar Bio Ecol. 2004; 302(1):85-106.
Lin SH, Chang CW, Iizuka Y, Tzeng WN. Salinities, not diets, affect strontium/calcium ratios in otoliths of Anguilla japonica. J Exp Mar Bio Ecol. 2007; 341(2):254-63.

Lin YJ, Jessop BM, Weyl OLF, Iizuka Y, Lin SH, Tzeng WN. Migratory history of African longfinned eel Anguilla mossambica from Maningory River, Madagascar: discovery of a unique pattern in otolith $\mathrm{Sr}$ :Ca ratios. Environ Biol Fishes. 2015; 98(1):457-68.

Lucas MC, Baras E. Migration of Freshwater Fishes. London: Blackwell Science Ltd; 2001.

Mai ACG, Condini MV., Albuquerque CQ, Loebmann D, Saint'Pierre TD, Miekeley N, et al. High plasticity in habitat use of Lycengrawulis grossidens (Clupeiformes, Engraulididae). Estuar Coast Shelf Sci. 2014; 141:17-25.

Martin GB, Thorrold SR, Jones CM. Temperature and salinity effects on strontium incorporation in otoliths of larval spot (Leiostomus xanthurus). Can J Fish Aquat Sci. 2004; 61(1):34-42.

McDowall RM. Anadromy and homing: two life-history traits with adaptive synergies in salmonid fishes? Fish Fish. 2001; 2(1):78-85.

Ministerio de Agroindustria (MINAGRO). Title of report. Argentina: Subsecretaría de Pesca y Acuicultura 2016. Available from: http://www.agroindustria.gob.ar/sitio/areas/ pesca_continental/index.php

Morales-Nin B, Pérez-Mayol S, Palmer M, Geffen AJ. Coping with connectivity between populations of Merluccius merluccius: An elusive topic. J Mar Syst. 2014; 138:211-19.

Neiff JJ. El régimen de pulsos en ríos y grandes humedales de Sudamérica. In: Malvárez AI, editor. Tópicos sobre humedales subtropicales y templados Sudamérica. Montevideo: UNESCO; 1999. p.90-150.

National Institute of Standards and Technology (NIST). Certificate of Analysis-Standard Reference Material 612. Gaithersburg. 2012.

Pearce NJG, Perkins WT, Westgate JA, Gorton MP, Jackson SE, Neal CR, et al. A compilation of new and published major and trace element data for NIST SRM 610 and NIST SRM 612 glass reference materials. Geostand Newsl. 1997; 21(1):115-44.

Potter IC, Tweedley JR, Elliott M, Whitfield AK. The ways in which fish use estuaries a refinement and expansion of the guild approach. Fish Fish. 2015; 16(2):230-39.

Subsecretaría de Actividades Pesqueras (SAP). Disposición 04/00 y expediente 2784-001/2000. 2000.

Secor DH, Rooker JR. Is otolith strontium a useful scalar of life cycles in estuarine fishes? Fish Res. 2000; 46(1-3):359-71.

Shrimpton JM, Warren KD, Todd NL, Mcrae CJ, Glova GJ, Telmer $\mathrm{KH}$, et al. Freshwater movement patterns by juvenile Pacific salmon Oncorhynchus spp. before they migrate to the ocean: Oh the places you'll go!. J Fish Biol. 2014; 85(4):987-1004.

Sinclair DJ, Kinsley LPJ, McCulloch MT. High resolution analysis of trace elements in corals by laser ablation ICP-MS. Geochim Cosmochim Acta. 1998; 62(11):1889-901.

Smith WE, Kwak TJ. Otolith microchemistry of tropical diadromous fishes: spatial and migratory dynamics. J Fish Biol. 2014; 84(4):913-28. 
Speranza ED, Cappelletti N, Migoya MC, Tatone LM, Colombo JC. Migratory behaviour of a dominant detritivorous fish Prochilodus lineatus evaluated by multivariate biochemical and pollutant data. J Fish Biol. 2012; 81(2):848-65.

Stassen MJM, Preeker NL, Ragas AMJ, van de Ven MWPM, Smolders AJP, Roeleveld N. Metal exposure and reproductive disorders in indigenous communities living along the Pilcomayo River, Bolivia. Sci Total Environ. 2012; 427:26-34.

Sturrock AM, Trueman CN, Darnaude AM, Hunter E. Can otolith elemental chemistry retrospectively track migrations in fully marine fishes? J Fish Biol. 2012; 81(2):766-95.

Sverlij SB, Espinach Ros A, Ortí G. Synopsis de los datos biologicos del Sabalo Prochilodus Lineatus (Valenciennes, 1847). Roma: Food and Agriculture Organization of the United Nations (FAO); 1993 (sinopsis sobre la pesca; No. 154).

Taylor W. Change-Point Analyzer 2.0 Shareware Program. Illinois: Taylor Enterprises; 2000.

Tzeng WN, Chang CW, Wang CH, Shiao JC, Iizuka Y, Yang YJ, et al. Misidentification of the migratory history of anguillid eels by $\mathrm{Sr} / \mathrm{Ca}$ ratios of vaterite otoliths. Mar Ecol Prog Ser. 2007; 348:285-95.
Van De Vis H, Kestin S, Robb D, Oehlenschläger J, Lambooij B, Münkner W, et al. Is humane slaughter of fish possible for industry? Aquac Res. 2003; 34(3):211-20.

Walther BD, Dempster T, Letnic M, McCulloch MT. Movements of diadromous fish in large unregulated tropical rivers inferred from geochemical tracers. PLoS One. 2011; 6(4):e18351.

Wynne MLP, Wilson KA, Limburg KE. Retrospective examination of habitat use by blueback herring (Alosa aestivalis) using otolith microchemical methods. Can J Fish Aquat Sci. 2015; 72(7):1073-86.

Yoshinaga J, Nakama A, Morita M, Edmonds JS. Fish otolith reference material for quality assurance of chemical analyses. Mar Chem. 2000; 69(1-2):91-97.

Submitted January 17, 2017

Accepted July 6, 2017 by Franco Teixeira de Mello 